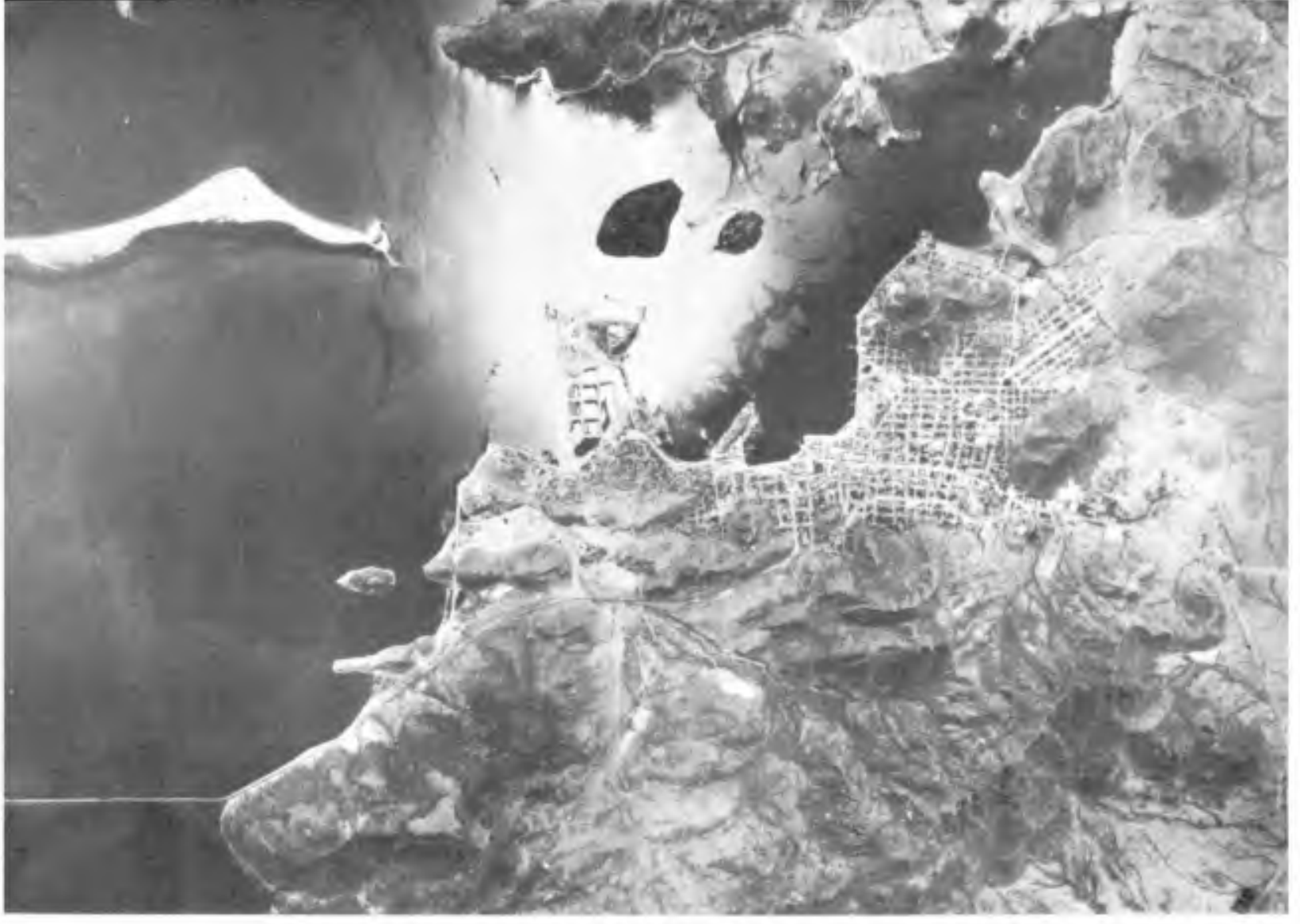

GUAYMAS

PART 4

COASTAL ENGINEERING PROBLEMS

Vera Cruz

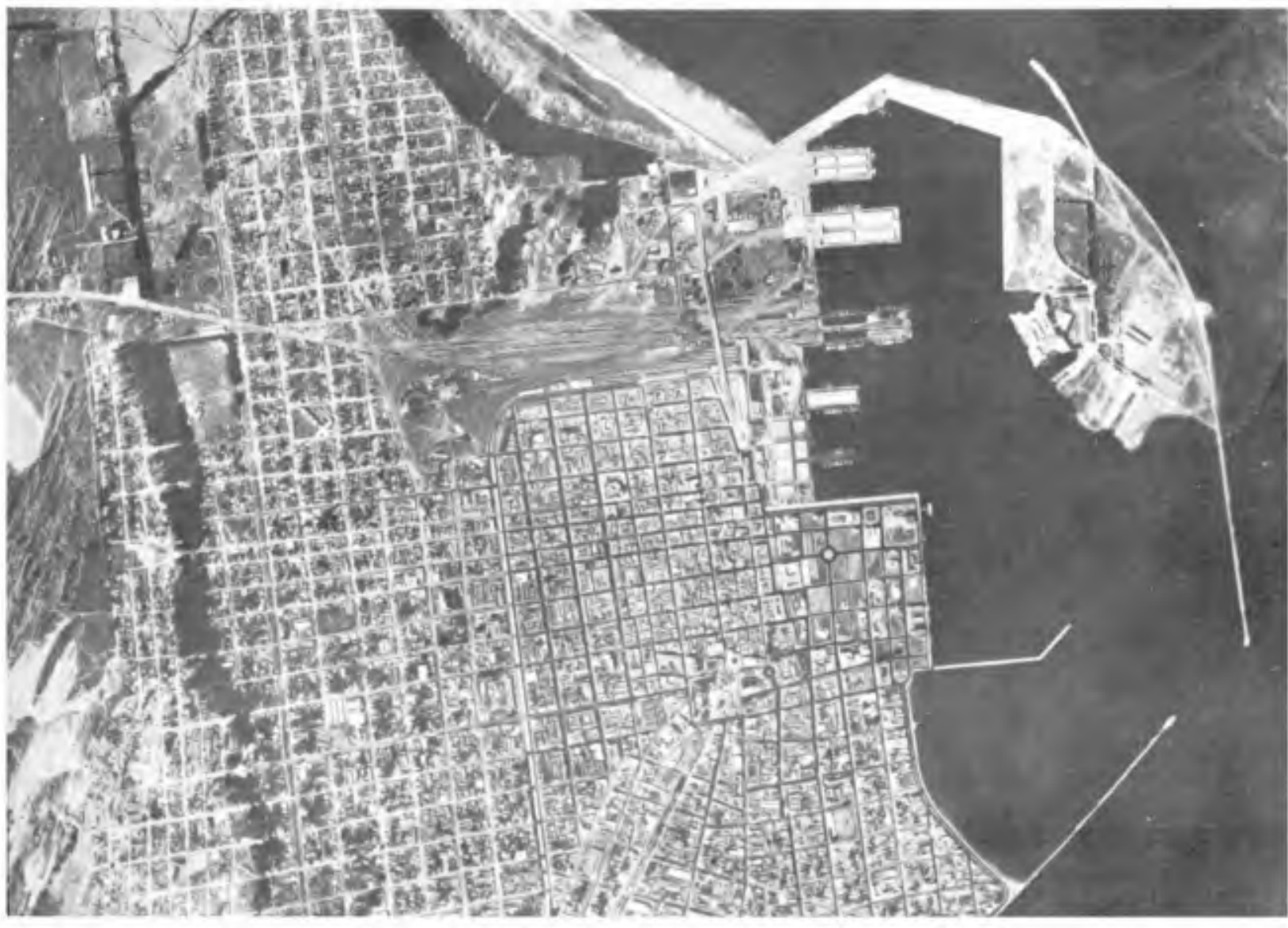



CHAPTER 31

\title{
DEEP WATER WAVES GENERATED BY HURRICANE "AUDREY" OF 1957
}

\author{
Basil W. Wilson \\ Senior Staff, National Engineering Science Company \\ Pasadena, California
}

\begin{abstract}
A post-mortem analysis of Hurricane Audrey of June 24-27, 1957, in the Gulf of Mex$i c o$, is described using all available ship reports and weather data from USA and Mexican sources. A detailed meteorological analysis defines the changing surface pressure and wind systems at 3-hour intervals, from which the space-time wind-fields have been derived for selected paths of wave generation bearing on the Louisiana coastline. A numerical technique of moving-fetch wave-prediction has been used to determine the characteristics of the waves in deep water that would have been prevalent in various parts of the Gulf of Mexico during pass age of the hurricane. For two deep water locations in particular the effects of multi-directional wave generation are considered.
\end{abstract}

\section{INTRODUCTION}

Hurricane "Audrey" of June 24-27, 1957, will long be remembered as a vicious killer-storm which brought stark tragedy and destruction to the Louisiana-Texas coast and to the town of Cameron, Louisiana, in particular. Coming hard on the heels of the disastrous series of hurricanes of 1954, 1955 and 1956, which devastated the eastern seaboard of the United States, it spurred the research then already beginning through the organization of the National Hurricane Research Project in 1956. On this account the features and effects of hurricane Audrey were particularly well documented [Weather Bureau, 1958] and made this storm a natural choice early in 1959 for a wave study designed to examine what was then still a relatively new and unproved procedure in wave forecasting [Wilson, 1955(i), (ii), (iii)]. 


\section{COASTAL ENGINEERING}

The essence of this procedure is that it removes completely any subjectivity in the definition of fetch and duration over which waves are under wind domination; it caters for the moving stor $m$ and for variable winds within the storm, and though its limitation in the first instance is uni-directional, it may be shown that it is capable of yielding the multidirectional effects of wave generation and, ultimately, precise information on the spectral composition of the sea at any point in space and time [Wilson, 1962].

The original graphical technique [Wilson, 1955] has been adapted to a numerical process [Wilson, 1961] permitting extremely rapid calculation of large amounts of input wind data by means of high speed computers. What is described herein are essentially the results of deep water wave predictions made in respect of hurricane Audrey on a modern No. 709 IBM (International Business Machines) electronic computer. As the technique itself has been fully described already [Wilson, 1961], no attempt will be made here to retrace the arguments upon which it is based; suffice it to say that the method depends on empirical relationships governing the observed properties of waves generated by uniform winds blowing steadily, without cessation, over finite fetches of deep water.

\section{THE WEATHER STRUCTURE OF HURRICANE AUDREY}

To secure the greatest amount of available data for determining the surface wind structure of hurricane Audrey during its lifetime over water, recourse was had to the assembled data of the National Weather Records Center [Weather Bureau, 1958], together with data kindly supplied by the Instituto de Meteorologia Nautica [Servicio Meteorologico Mexico 1959]. Valuable data were also secured from A. H. Glenn [1959] in the form of weather maps, pressure and wind information and a report to the offshore oil industry [Lindblom, 1957], which was essentially a rapid analysis of the storm and its effects in coastal waters. A partial analysis was also available in an unpublished report of the Weather Bureau [Hudson, 1957] and other useful information was found in descriptions of the hurricane given in the Monthly Weather Review [ Ross and Blum, 1957; Moore, et al, 1957], and elsewhere [Sartrain, 1957; Corps of Engineers, 1957; Visser, 1957; Cross, 1957; Zumwalt, 1958; Harris, 1958; Skjelbreia, 1958]. In addition, a limited amount of actual wind data in the form of visual readings and automatic traces of anemometers at coastal stations and offshore drilling digs was obtained from offshore oil and mining industry sources [Freeport Sulphur Co., 1959; Kerr-McGee Oil Industries, Inc., 1959].

All these data were carefully screened and integrated into the series of synoptic maps of surface pressure (Figs. 1 to 5 ) and surface wind velocity (Figs. 7 to 11 ) over the Gulf of Mexico. These maps, how ever, are almost entirely complete re-analyses of the weather situation, elaborated rather painstakingly from ship and land station reports and 


\section{DEEP WATER WAVES GENERATED BY HURRICANE- "AUDREY" OF 1957}

adjusted for consistency by close attention to trends of change at the 3hour intervals for which, in the main, they are compiled.

An early difficulty was non-agreement of the locations of the eye of the hurricane at the different times, as given by the Weather Bureau [Hudson, 1957], by A. H. Glenn [Lindblom, 1957], by Visser [1957] and by Skjelbreia [1958]. The Weather Bureau track was ultimately judged to be the most accurate and fitted best with the pressure patterns evolved from ship reports. This essentially is the track shown in Figs. 1 to $5 ; 7$ to 11 , though it bears slightly more to the east at its coastal crossing than that of the Weather Bureau.

Inspection of Fig. 1(a) shows that hurricane Audrey had formed with a weak pressure center in the Gulf of Campeche at 0300 CST on June 24, 1957. An easterly storm front is there revealed crossing the west end of the Yucatan peninsula. By 1200 CST of the same day (Fig. 1b) the low pressure centers had apparently coalesced like two amoebae and the pressure pattern distorted by the impending dissipation of the front. The gain in strength of the hurricane, moving slowly at first, can be noticed by the expanding diameter of the $1010 \mathrm{mb}$. contour and by the successive expansions of the 1005 and $1000 \mathrm{mb}$. rings in Figs. 1 to 5 .

As far as can be judged the hurricane moved erratically along its path at speeds of progression which fluctuated considerably, as shown in Fig. 6. These speeds were evaluated from a distance-time plot of the storm's forward advance and are probably reasonably accurate. The mean forward speed was about 13 knots.

Figs. 1 to 5 do not attempt to record central pressures at $1 \mathrm{mb}$ intervals below about $1000 \mathrm{mb}$ because of the density of the concentric isobars near the storm center. As the hurricane approached the Louisiana Coast (Fig. 5), pressures near the center were somewhat better defined by the increasing number of observations, permitting reasonable identification of pressure levels to as low as $980 \mathrm{mb}$, (Fig. 5d). For purposes of computıng surface wind velocities near the hurricane center during transit over water it was necessary, however, to determine the probable central pressures $p_{0}$ and radii $R$ to zones of maximum wind velocity. Values of central pressure over the ocean shown in Fig. 6(a) are based largely on Weather Bureau (Naval) aerial reconnaissance advisories as is sued by Glenn [Lindstrom, 1957] and on the fortunate fact that at least two ships were caught in the eye of the hurricane and recorded central conditions. The trend of fall of pressure, shown in Fig. 5(a), from about $1008 \mathrm{mb}$ to the $971 \mathrm{mb}$ level at the time of the hurricane's crossing of the Louisiana coastline was established also from extrapolations of the pressure profile of the synoptic maps of Figs. 1, 2 and 5. There is some descrepancy between the lowest pressure of $971 \mathrm{mb}$ found collectively in this way and the much lower pressures of $958 \mathrm{mb}$ and $967 \mathrm{mb}$ apparently recorded respectively at Hackberry, La. ( 2 miles from the storm track) and at Port Ar- 


\section{COASTAL ENGINEERING}

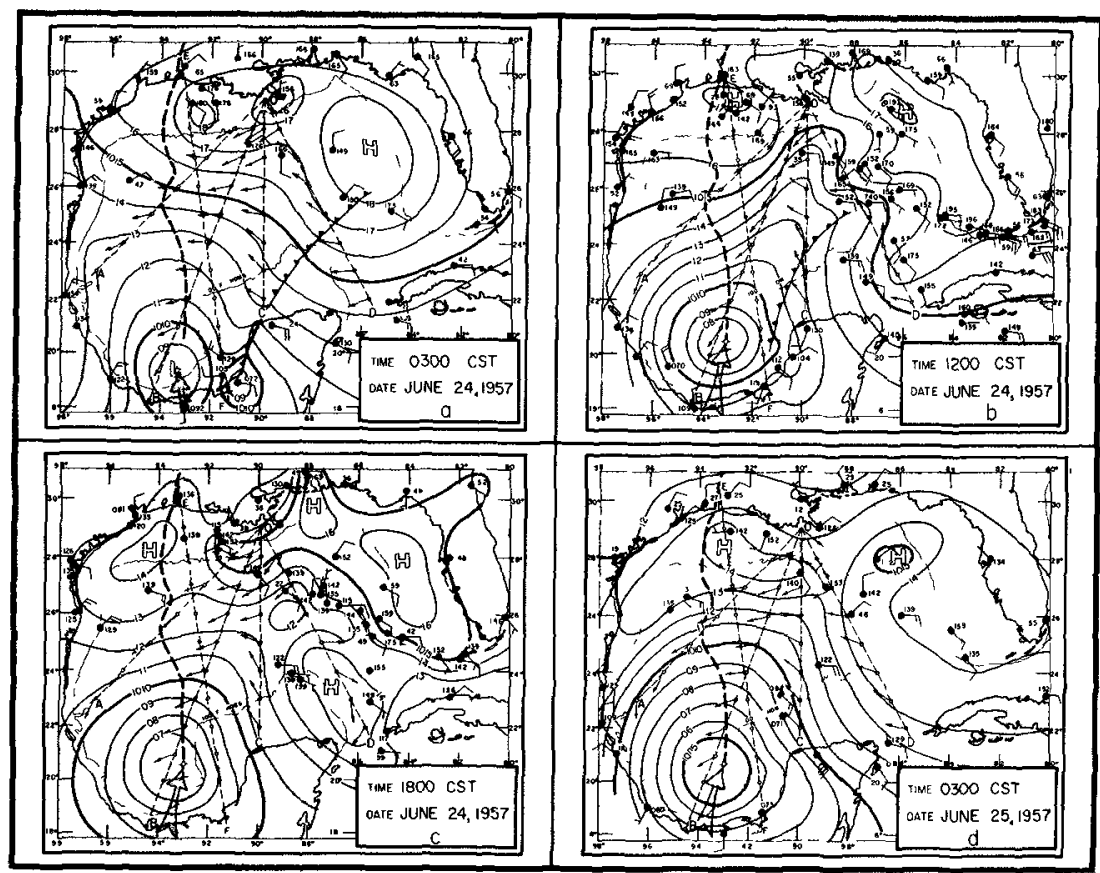

Fig. I. Synoptic surface pressure patterns (mbs) for the Gulf of Mexico, 0300 CST, June 24, to 0300 CST, June 25, 1957.

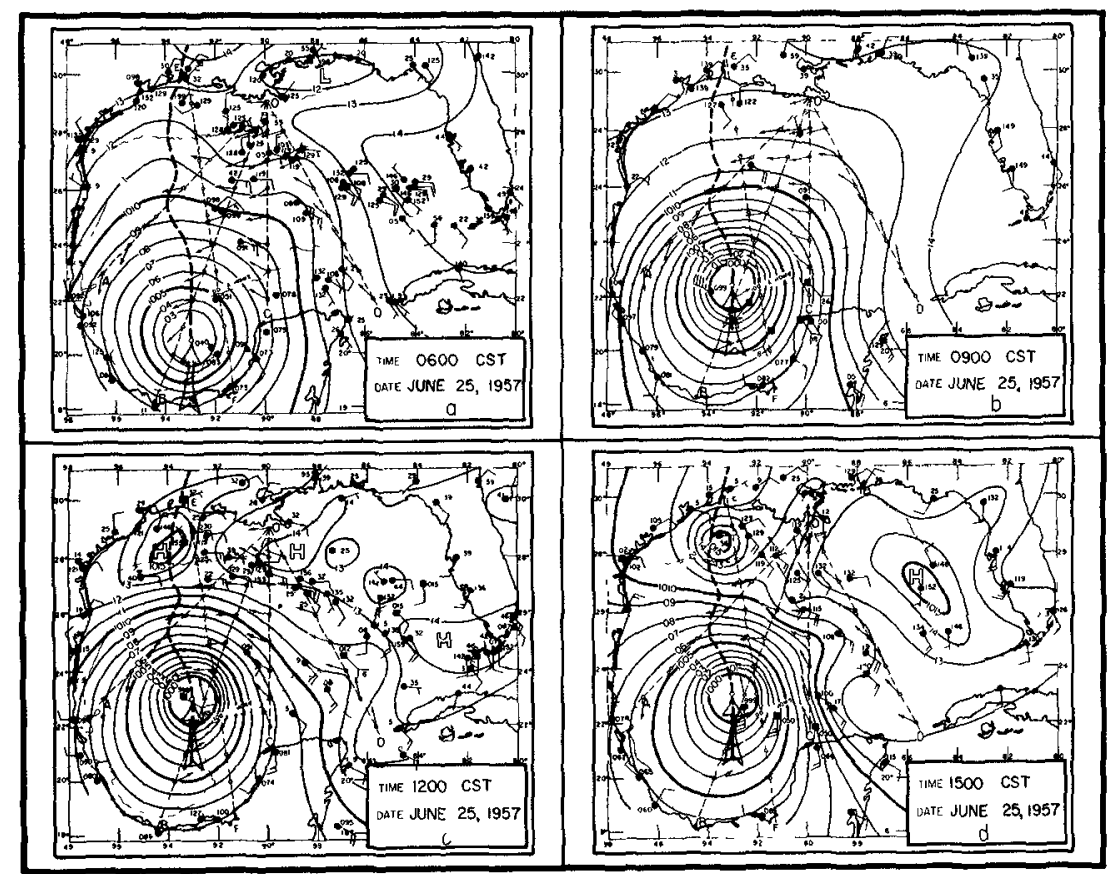

Fig. 2. Synoptic surface pressure patterns (mbs) for the Gulf of Mexico, 0600 - 1500 CST, June 25, 1957. 


\section{DEEP WATER WAVES GENERATED BY HURRICANE "AUDREY" OF 1957}

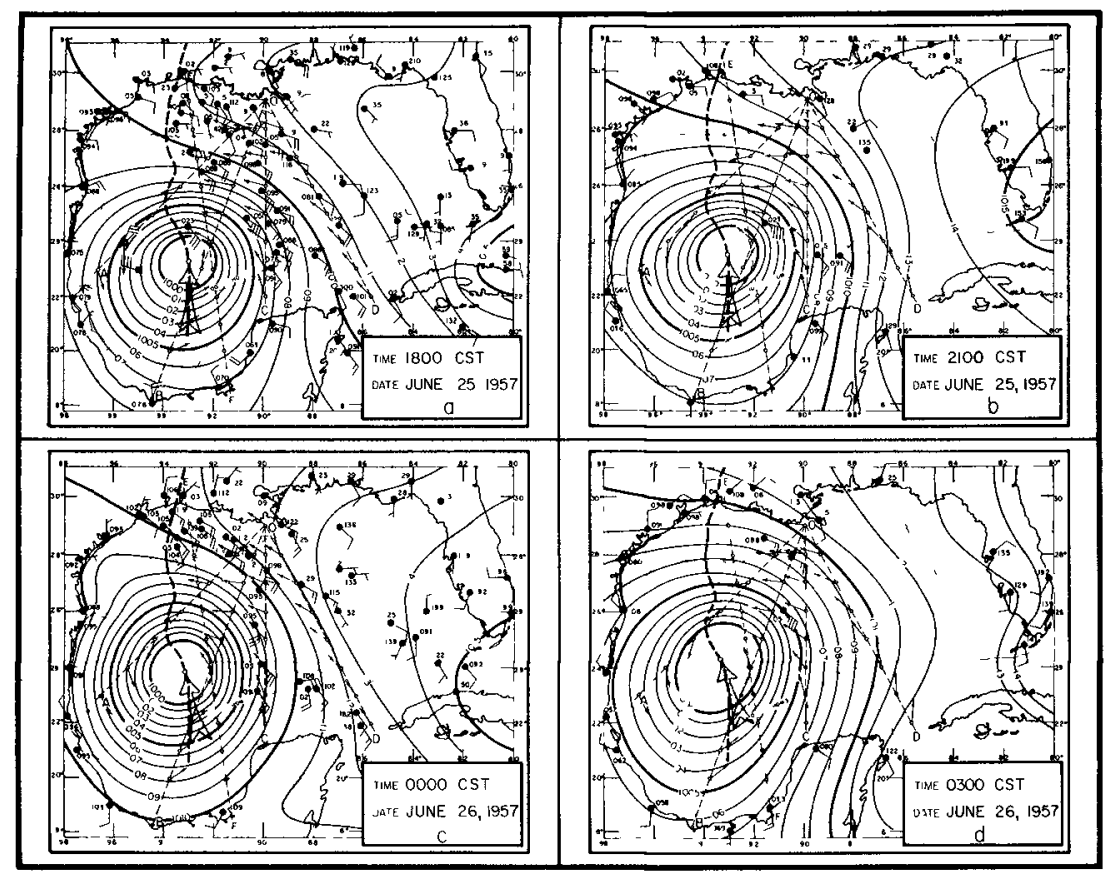

Fig. 3. Synoptio surface pressure patterns (mbs) for the Gulf of Mexico, 1800 CST, June 25, to 0300 CST, June 26, 1957.

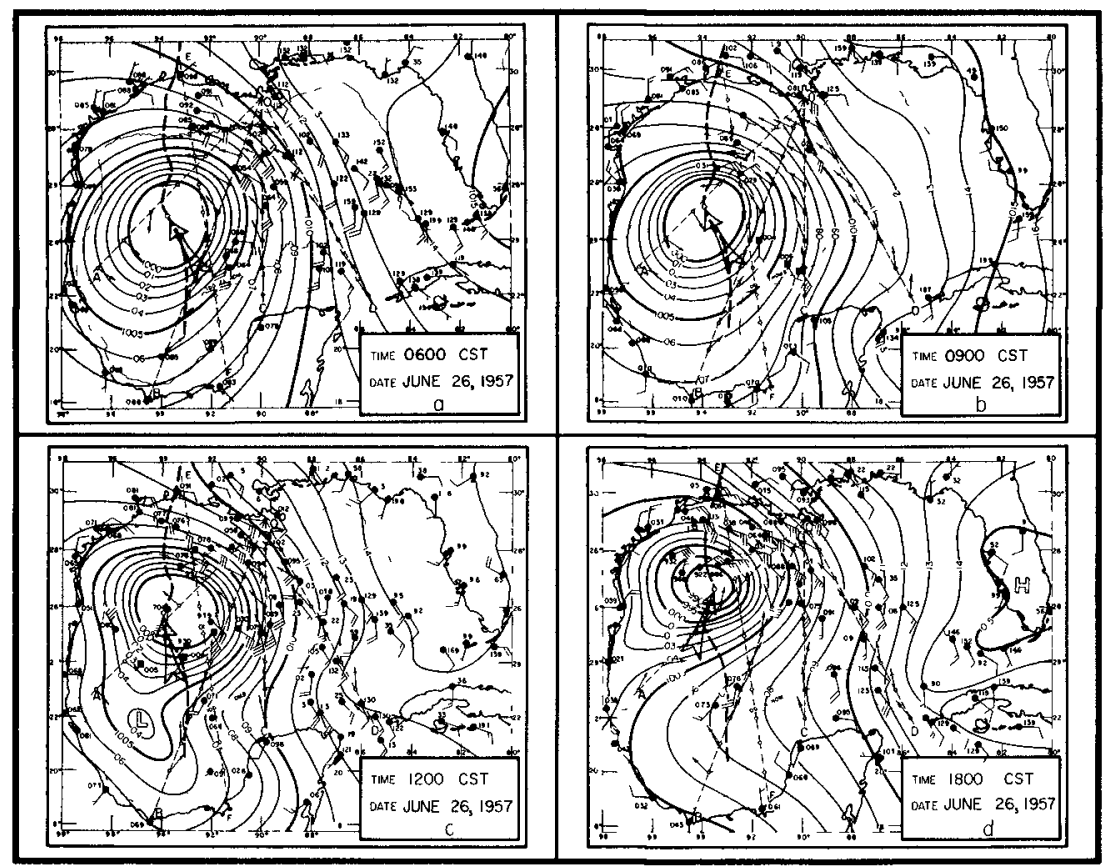

Fig. 4. Synoptic surface pressure patterns (mus) for the Gulf of Jexico, 0600 - 1800 CST, June 26, 1957. 


\section{COASTAL ENGINEERING}

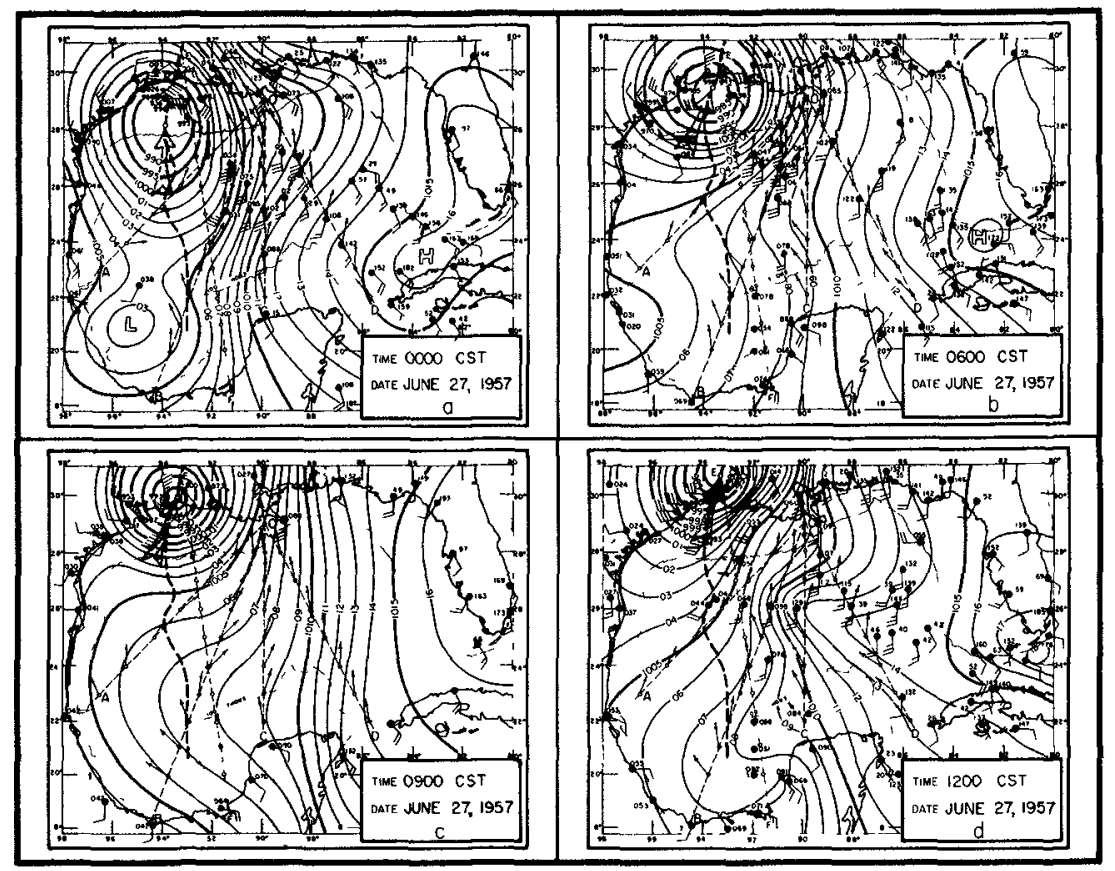

Fig. 5. Synoptic surface pressure patterns (mos) for the Gulf of Mexico, $0000-1200$ CST, June 27, 1957.
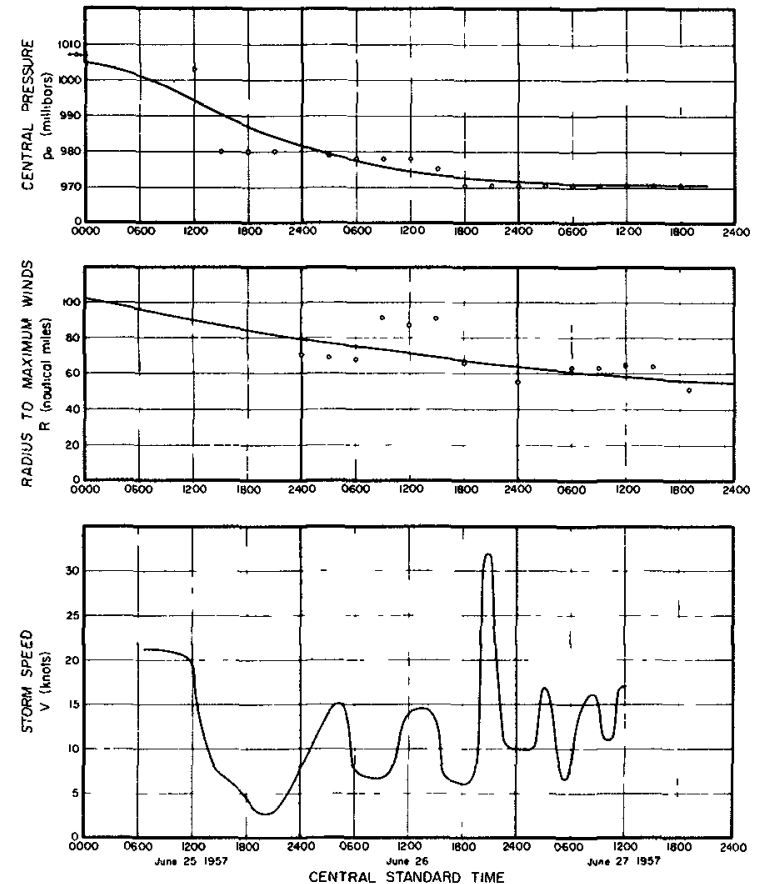

FIg. 6. Intensity, size and speed characteristios of hurricane Audrey (a) central pressure, $p_{0}$; (b) radius to maximum winds, $R$, (c) spe日d of advance. 


\section{DEEP WATER WAVES GENERATED BY HURRICANE "AUDREY" OF 1957}

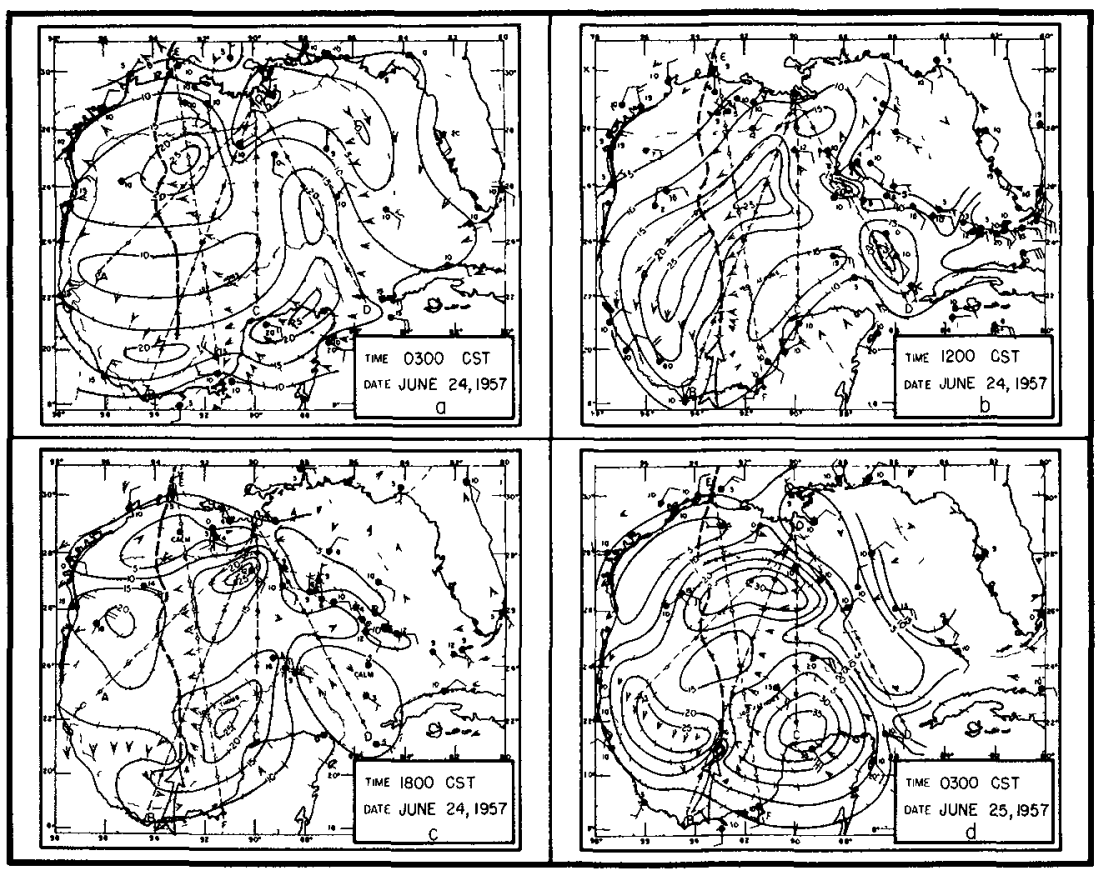

Fig. 7. Synoptic surface wind velocity (knots) and circulation patterns for the Gulf of Mexico, $0300 \mathrm{CST}$, June 24, to $0300 \mathrm{CST}$, June 25, 1957.

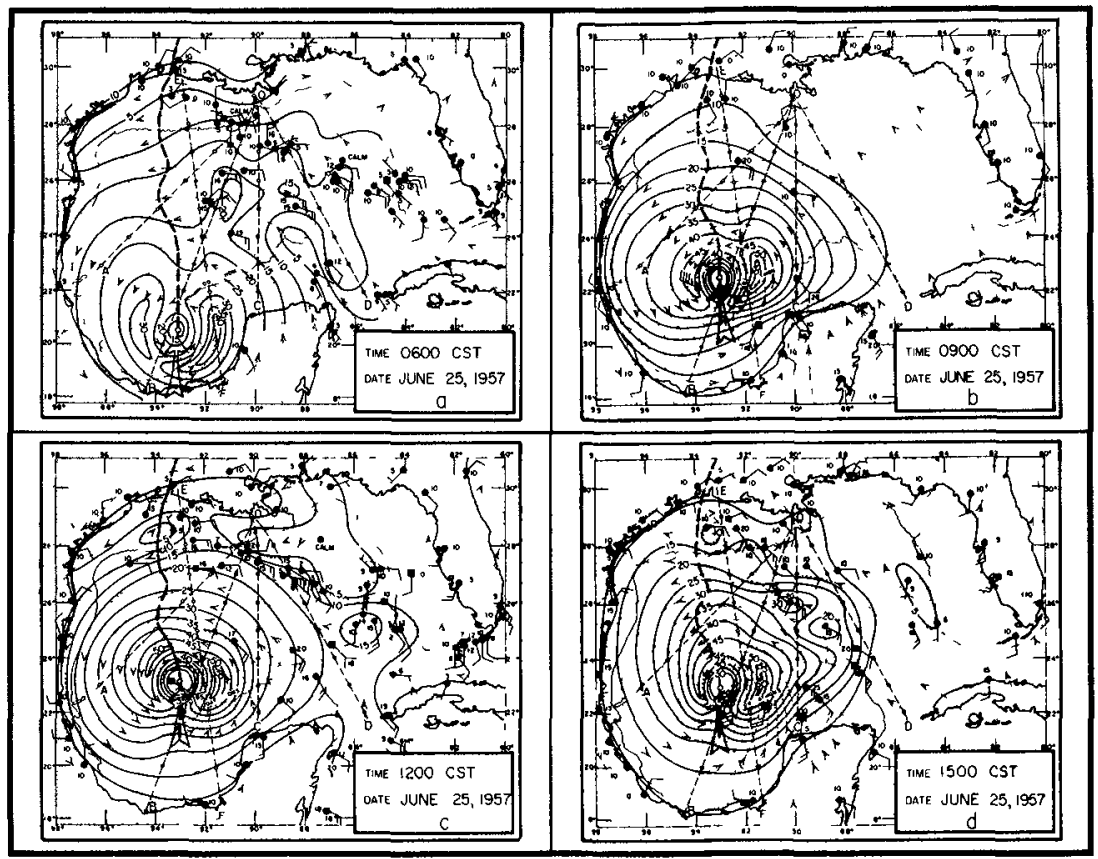

Fig. 8. Synoptic surface wind velocity (knots) and circulation patterns for the Gulf of Mexico, 0600 - 1500 CST, June 25, 1957. 


\section{COASTAL ENGINEERING}

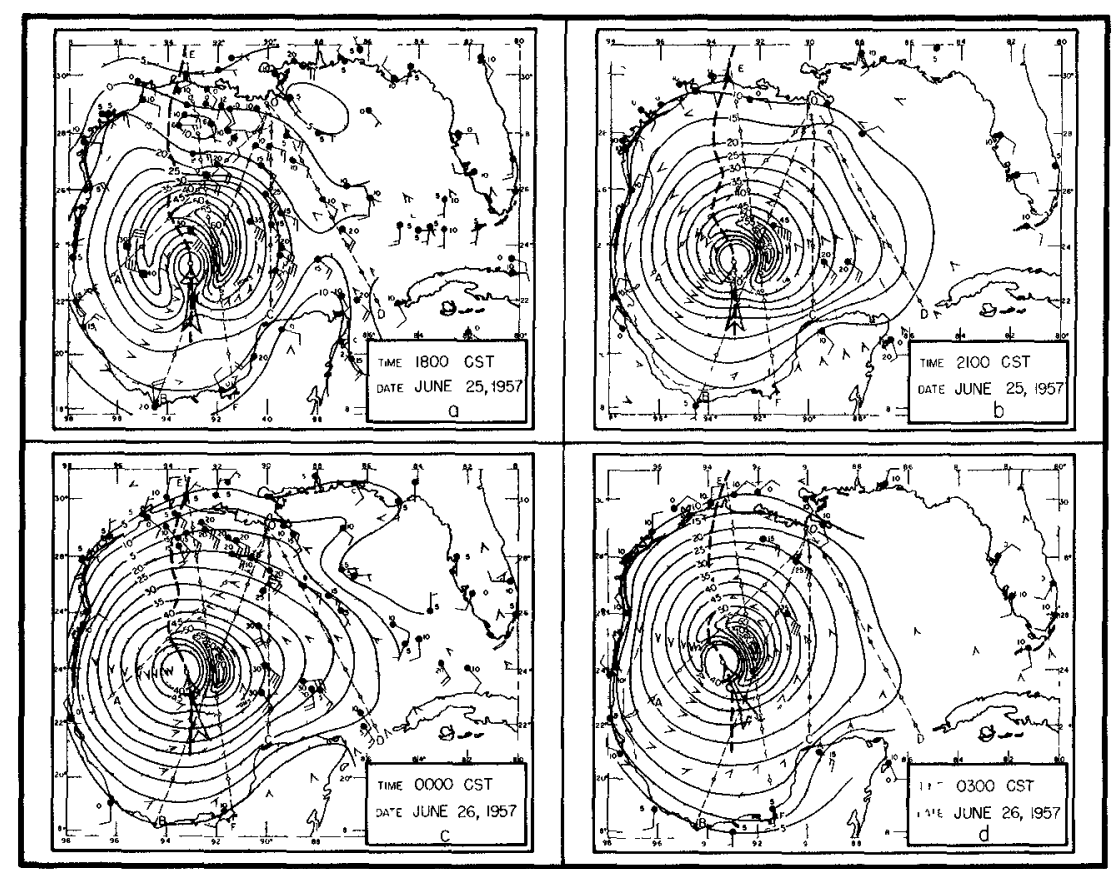

Fig. 9. Synoptic surface wind velocity (knots) and circulation patterns for the Gulf of Mexico, 1800 CST, June 25, to 0300 CST, June 26, 1957.

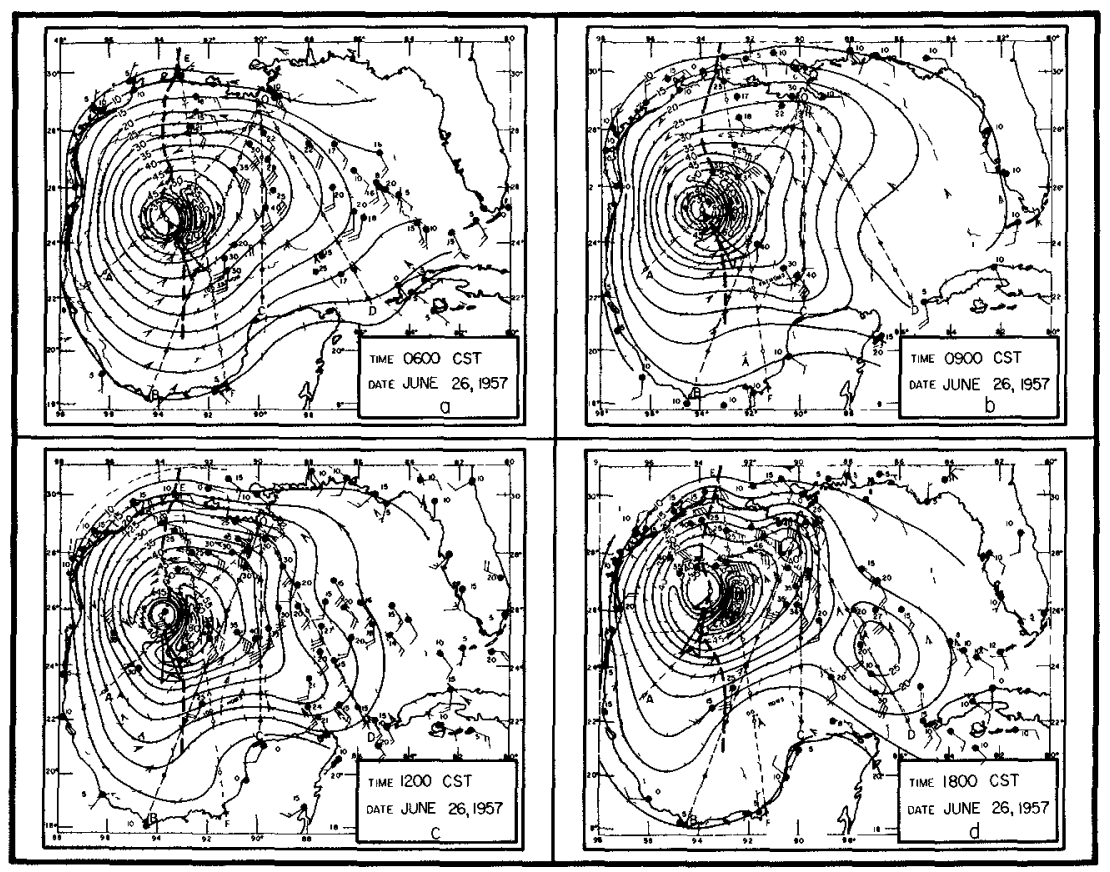

Fig. 10. Synoptic surface wind velooity (knots) and circulation patterns for the Gulf of Mexico, 0600 - $1800 \mathrm{CST}$, June $26,1957$. 


\section{DEEP WATER WAVES GENERATED BY HURRICANE "AUDREY" OF 1957}

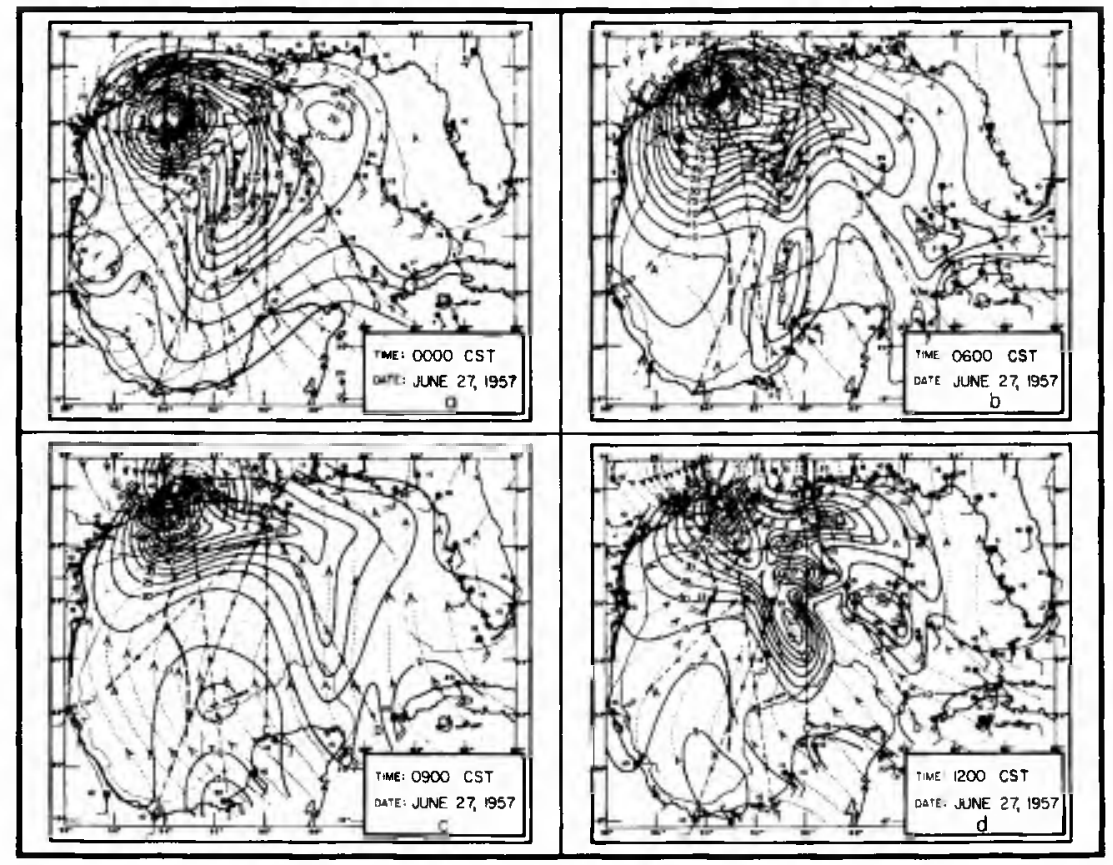

Fig. 11. Synoptic surface wind velocity (knots) and circulation patterns for the Gulf of Mexico,0J00 - 1200 CST, June 27, 1957.
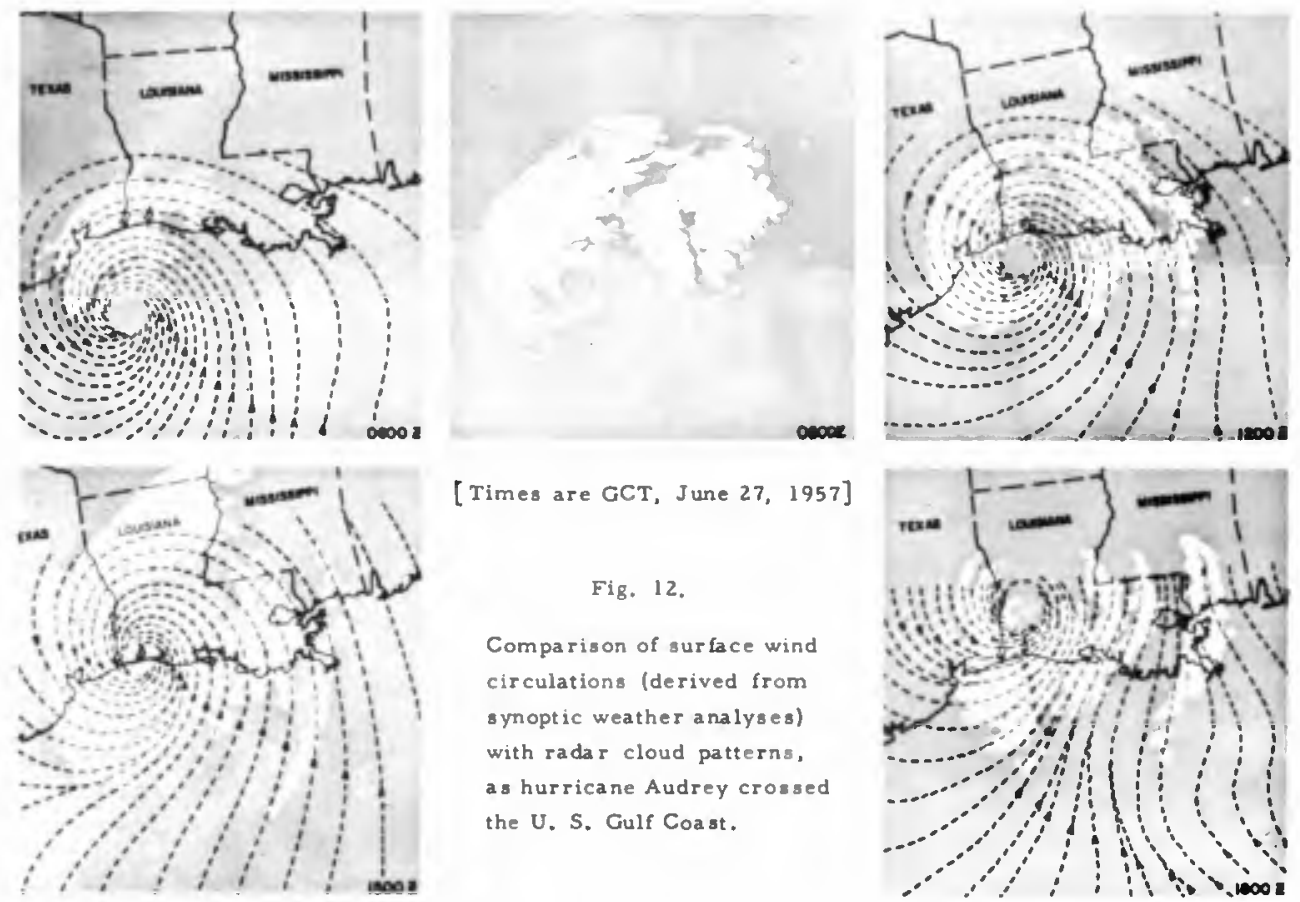

[Times are GCT, June 27, 1957]

Fig. 12 ,

Comparison of arface wind circulations (derived from synoptic weather analysea with radar cloud patterns, as hurricane Audrey crossed the U. S. Gulf Coast.

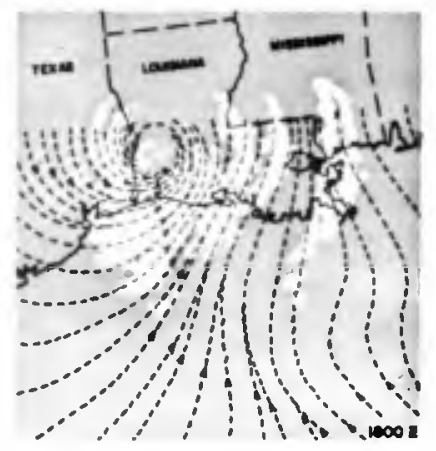

Fig. 12 


\section{COASTAL ENGINEERING}

thur, Texas ( $25 \mathrm{n}$. miles from the storm track), as reported by Graham \& Hudson [1960]. At Lake Charles, La., only $3 \mathrm{n}$. miles from the storm track, the lowest pressure recorded was only $971 \mathrm{mb}$, how ever, while the calibrated barometer reading of the American tanker "Tillamook", about $10 \mathrm{n}$. miles from the pressure center, was 973 $\mathrm{mb}$, when the storm was almost at the coast. The total available evidence does not favor the existence of a lower pressure than $971 \mathrm{mb}$ while the hurricane was still over water and the low values at Hackberry and Port Arthur must be ascribed to transient pressure fluctuations induced perhaps by the coastal crossing or to other unknown effects.

Graham and Hudson [1960] have concluded that hurricane Audrey crossed the coast with a probable lowest pressure $p_{0}=946 \mathrm{mb}$ and a radius to maximum winds $R=19 \mathrm{n}$. miles. Such a deep intense storm is again not supported by the available evidence over water. Thus, if the history of lowest pressure $p_{0}$ is accepted as that of Fig. 6(a), it.is found that the corresponding best-fit values of $R$ obtained by the spiral-diagram method [Wilson, 1957(i)(ii)] are those shown in Fig. 6(b). This method incorporates the same exponential pressure formula, given originally by Myers [1954], which was used by Graham and Hudson in arriving at their values of $p_{0}$ and $R$. Contrary to their interpretation, it suggests that Audrey crossed the coast at 0840 CST on June 27, 1957, with a radius to maximum winds $R \simeq 55 \mathrm{n}$. miles, already shrunk by almost a half from its value when the hurricane first formed in the Bay of Campeche.

Use of the mean line curves (Figs. $6 a$ and $b$ ) for $p$ and $R$ permitted spot calculations being made of wind velocities, at different times, in areas not covered by ship reports. These calculations followed procedures already used previously, [Wilson, 1957(i), (ii)]. The combined information on wind velocities and directions available from ship and land observations and from calculation were finally used in deriving the contours of wind velocity and directional stream-lines shown in the wind patterns of Figs. 7 to 11 . These had to withstand the overriding test for consistency that they show sequential trends of change at the 3-hour intervals for which the maps were constructed, and that they accommodate withal the scattered data of spot observations. It seems possible to claim for these analyses that they meet these requirements in the main, while being consistent with the radii to maximum winds, $R$, given in Fig. 6(b).

The wind patterns of Fig. 11, as the hurricane crossed the coast, are rather markedly different from those derived by Graham and Hudson [1960], but are quite akin to the wind pattern found by Glenn [Lindstrom, 1957], being distinguished by the channels of high wind which spiral or radiate out over the Gulf from the storm center. Figs. 7 to 11 show the gradual formation of the characteristic horse-shoe type wind-pattern of the hurricane with highest winds concentrating on the right-hand side of its track. Maximum winds are seen to increase 


\section{DEEP WATER WAVES GENERATED BY HURRICANE "AUDREY" OF 1957}

from about 40 knots at $0600 \mathrm{CST}$, June 25 , to about 88 knots (101 $\mathrm{mph}$ ) at the time that the storm crossed the coast near $0900 \mathrm{CST}$, June 27, 1957. All velocities shown are mean values and may be considered to fluctuate about the mean in gusts by approximately $\pm 45 \%$. One satis factory feature of the wind analysis is the degree of concurrence between the wind streamlines of Fig. 11 and the composite radar cloud patterns obtained from several shore-based radar stations. These cloud patterns are shown in Fig. 12 along with the surface wind streamlines, reproduced from Fig. 11 . Fig. 12 confirms that the center of the eye of the hurricane passed directly over Calcasieu Lake just west of Cameron, La., in agreement with the hurricane track adopted.

\section{WIND FIELDS FOR SELECTED DIRECTIONS}

For purposes of wave prediction, two areas of principal inter est were indicated at the outset of this study. One was the point $O$ in Figs. 1 to 5,7 to 11 , identified as the site of the California Company's offshore oil platform in Bay Marchand, Louisiana, and the other point $\mathrm{E}$, on the Louisiana coastline, just east of Cameron, which received the full brunt of the storm. Reliable wave data had been collected at the California Company platform [Skjelbreia, 1958], and point $O$ was therefore an obvious checkpoint for the wave predictions. Somewhat less accurate wave data were available for the Cameron area and the Louisiana coastline in general from the various sources already referred to in Section 2 .

It was decided to investigate wave conditions along five approach directions to the coast, four bearing on $O$ and one on $E$. The wave paths $A O, B O, C O$ and $D O$ conform closely to the $S W$, SSW, $S$ and $S E$ directions, respectively, converging on $O$; the wave path FE, on the other hand, was somewhat arbitrarily selected to parallel the track of the hurricane at a distance such that waves would be dominated by the highest possible winds for the longest period of time.

The wind-fields for these five wave paths are shown in Figs. 13 and 14. These show space-time plots of the components of wind velocity directed along each wave path. Contours define the velocity values in knots and shaded areas of the wind-field represent zones for which the wind components are headed toward the coast; white areas are zones of wind headed away from the coast. Limitations of cost made it necessary to restrict the areas of wind-field which could be investigated by the numerical prediction technique. Accordingly only the darker shaded zones of Figs, 13 and 14 were specifically investigated as likely to yield maximum wave conditions in the hindcast study. For these areas values of wind velocity were tabulated for each interval of $10 \mathrm{n}$. miles and 1 hour to provide the input (space-time lattice) data for the machine prediction of the waves [cf. Wilson, 1961]. 


\section{COASTAL ENGINEERING}

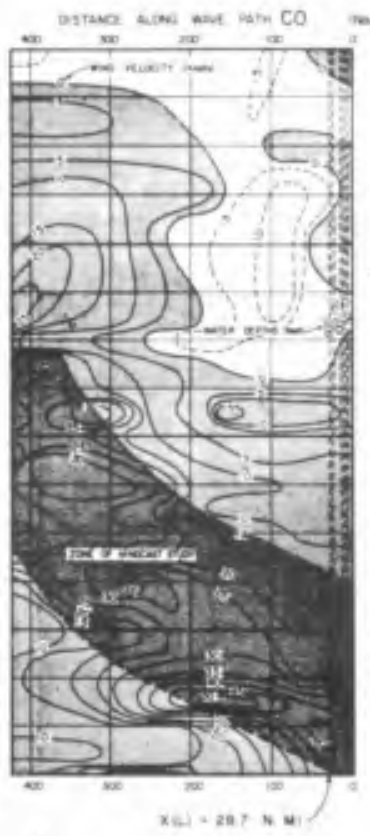

(a)

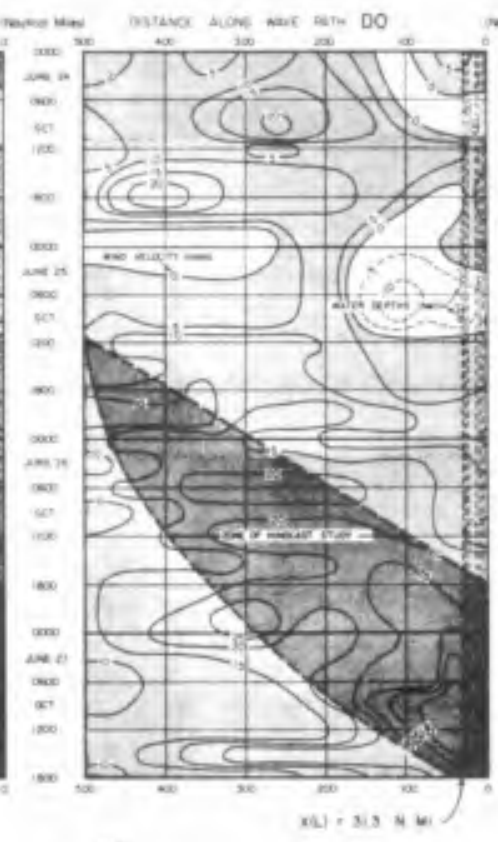

(b)

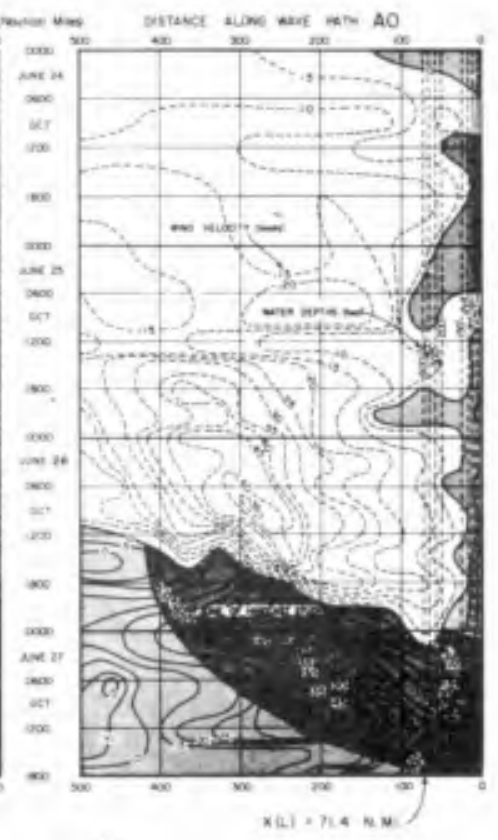

(c)

Fig. 13, Space-time wind-fields for hurricane Audrey along wave paths CO, $D O$ and $A O$ in the Gulf of Mexico.

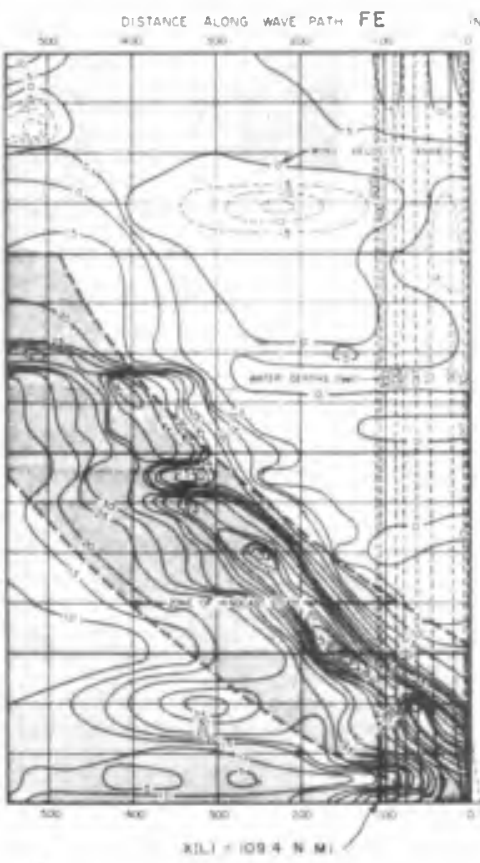

(a)

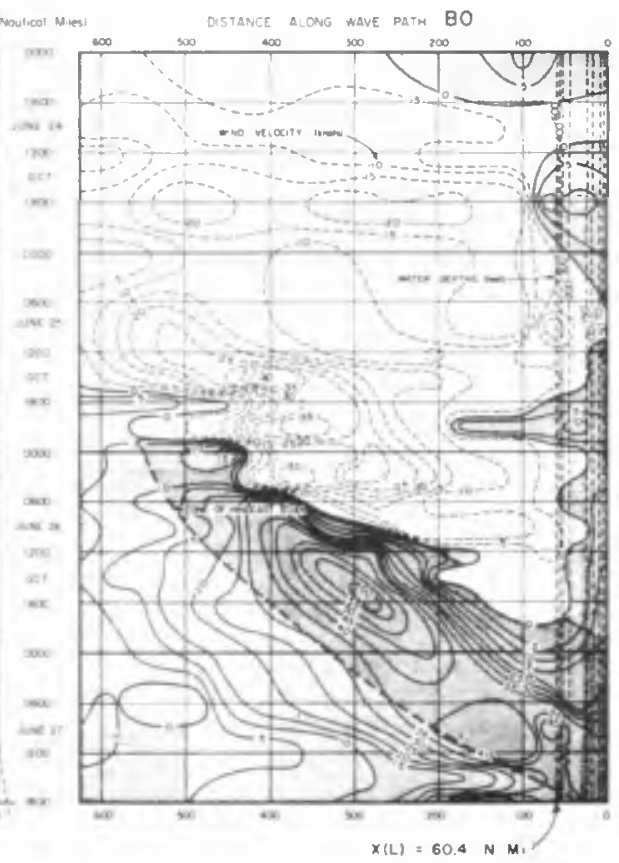

(b)

Fig. 14. Spece-time wind-fields for hurricene Audrey along wave paths FE and $B O$ in the Gulf of Mexico. 


\section{DEEP WATER WAVES GENERATED BY HURRICANE \\ "AUDREY" OF 1957}
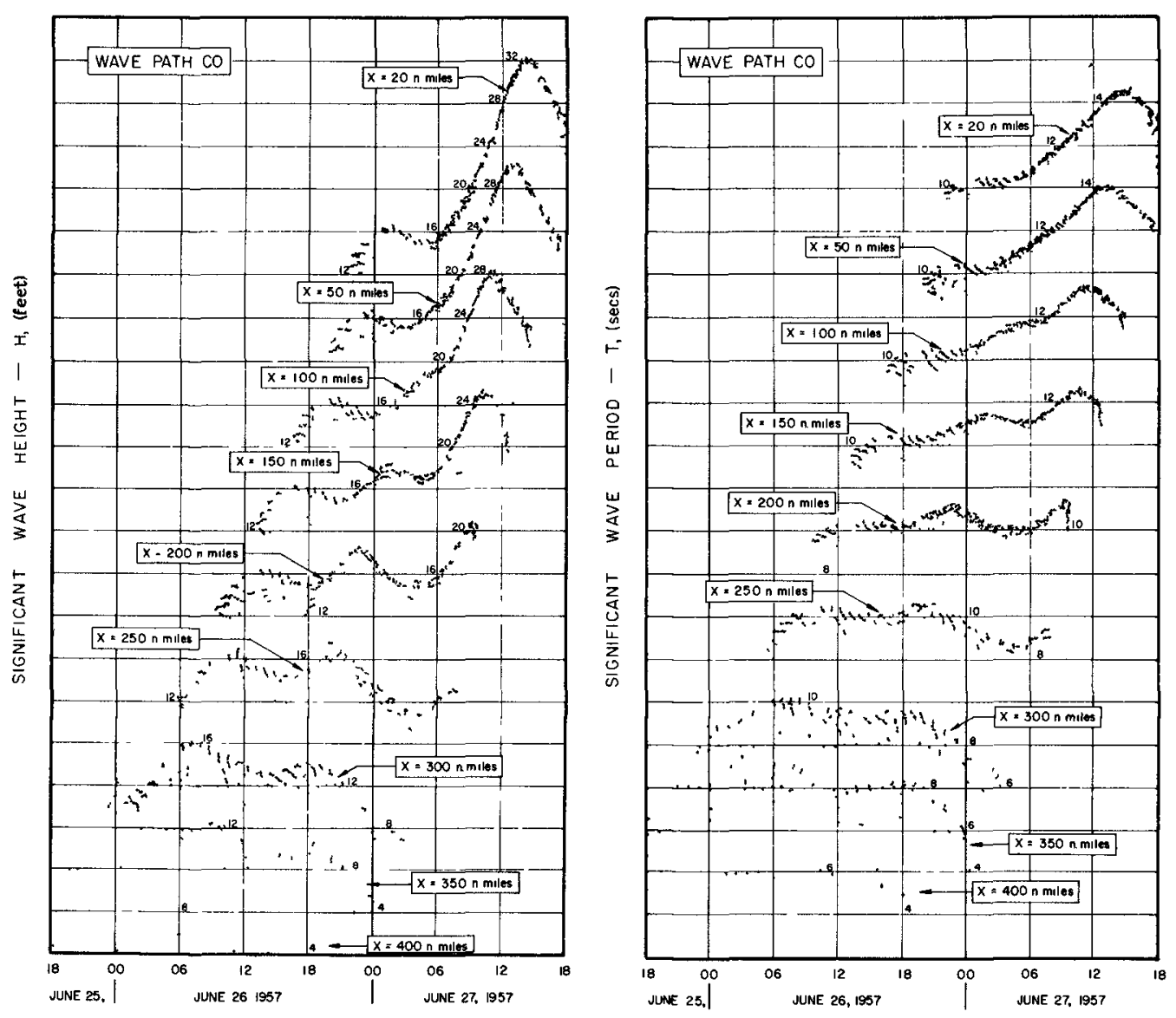

ELAPSED TIME, GCT

Fig. 15. Numerical computations of significant wave height and period at different distances from 0 along wave path $\mathrm{CO}$. 


\section{COASTAL ENGINEERING}

It is immediately apparent from Fig. 14 that the wave paths FE and $B O$ provide zones of highest wind velocity directed respectively towards $E$ and $O$ and that the highest waves may be expected to occur in these directions. Next to BO, wave path AO (Fig. 13) conceritrates the highest winds bearing on station $O$.

\section{DEEP WATER WAVE PREDICTIONS}

In the hindcast procedure [Wilson, 1961] each space-time lattice point of wind input-data provides the starting point for an independent wave height and period computation along a particular wave path. Since the computation can be made to yield the significant wave height and period at any point along the wave path, it is possible to extract as output data all the possible heights and periods, with times of occurance, predicted for selected points along the wave path, such as every $50 \mathrm{n}$. miles from the coastal station. Fig. 15 is an example of these results as applicable to the wave path CO. Each plotted point of these figures represents the significant wave height (or period) occuring at the indicated time after starting from some reticulation point of the wind field in Fig. 13(a). In general the plotted points fall in a scatter with a well-defined upper-bound, to which an envelope curve is easily fitted. In the uppermost diagrams of Fig. 15, the scatters of points below the boundaries have been largely omitted for obvious reasons. Only the envelope itself is held to have significance as the time history of significant wave height (or period) at the indicated distance along the wave path.

When the envelope curves themselves are superimposed on each other the results appear in the form of Fig. 16. Along a southerly approach to station $O$ in Bay Marchand, La., it is seen that at the distance of $400 \mathrm{n}$. miles (off Yucatan), significant wave heights at no time exceeded about $5 \mathrm{ft}$, nor the periods about 6.5 secs. Heights and periods increase as the distance lessens towards $O$ and, as might be expected, the peak waves occur at increasingly later times. The final prediction for the wave path $C O$ is at the distance of $20 \mathrm{n}$. miles, which defines the edge of the continental shelf off Louisiana. Between this point and the station $O$ the waves would have to trans gress shallow water and the computation technique would have to be rather radically altered to allow for this fact. It is unfortunately not possible within the limits of the present paper to enter into the complications of the continuing shallow water generation of the waves.

The corresponding sets of envelope curves of wave paths $\mathrm{AO}$, $B O, D O$ and $F E$ are portrayed in Figs. 17 to 20 . As expected, wave paths $B O$ and $F E$ yield the largest waves with significant wave heights, $H$, and periods $T$, of $H=40 \mathrm{ft}, T=16$ secs for $B O$ and $H=46 \mathrm{ft}$, $T=17$ secs for $F E$. 


\section{DEEP WATER WAVES GENERATED BY HURRICANE "AUDREY" OF 1957}
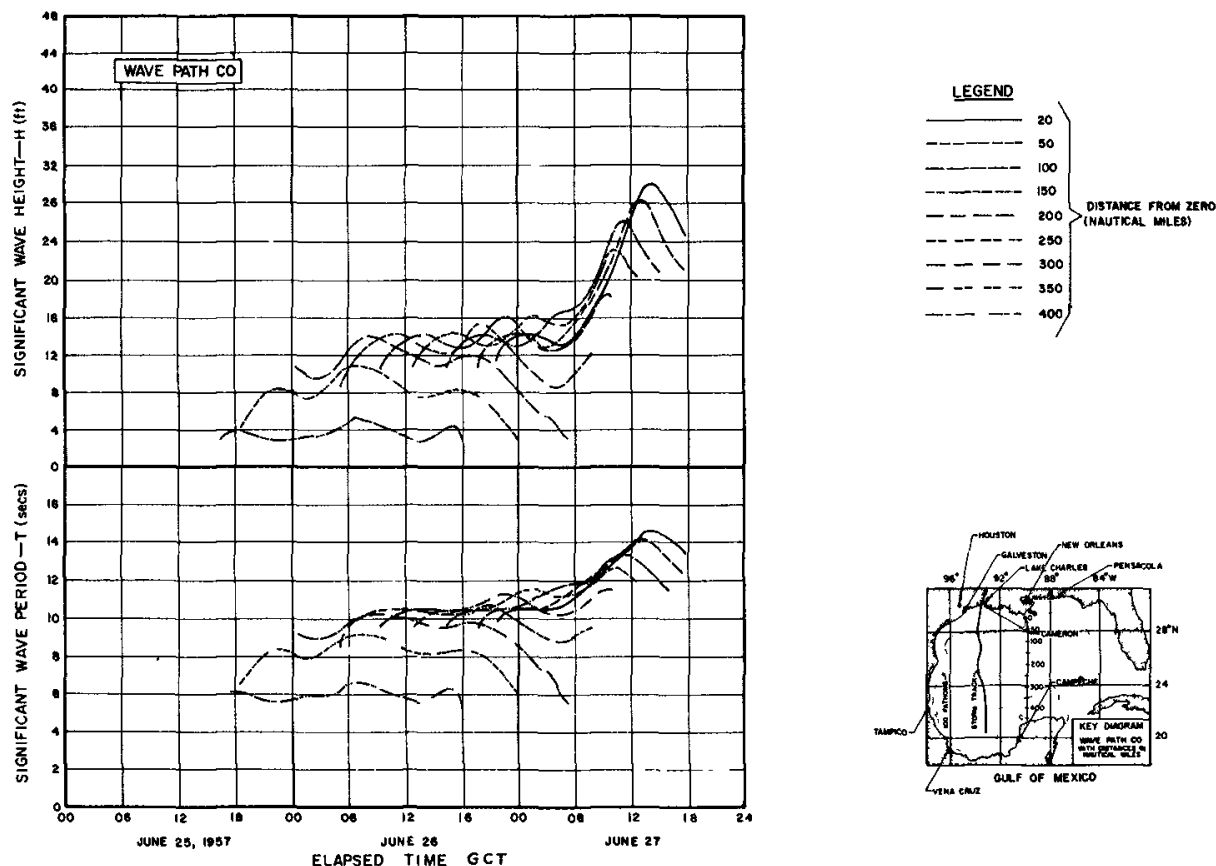

Fig. 16. Envelopes from Fig. 15 superimposed to record time-histories of significent wave height and period at different distances along wave path CO.
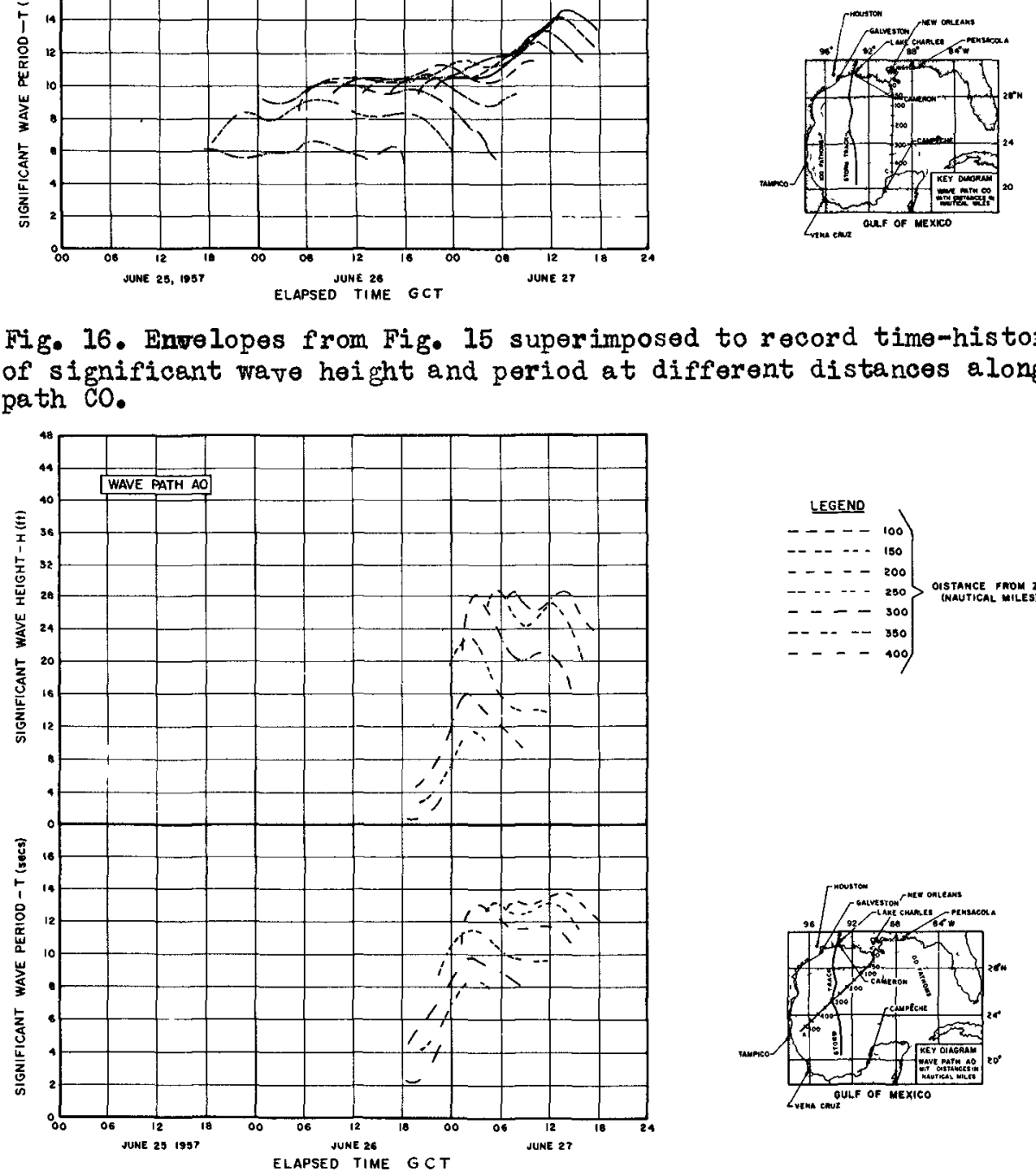

Fig. 17. Invelope histories of significant wave height and period at different distances along wave path $\mathrm{AO}$. 


\section{COASTAL ENGINEERING}

At the distance of $300 \mathrm{n}$. miles along the wave path $F E$ (Fig. 20) an interesting double peak is indicated by the trend of the envelope curves. Reference to the wind field in Fig. 14(a) suggests that this is the result of the two separated zones of high wind velocity falling to the left of the $300 \mathrm{n}$. mile distance mark.

\section{MULTI-DIRECTIONAL WAVE EFFECTS}

The uni-directional concept in deep-water wave prediction techniques has hitherto left unanswered what the interference effects may be of waves generated along a multiplicity of directions, all of which converge to a point. The present study offers some insight into this aspect, for it is conveniently found that the intersection point $G$ between wave paths FE and AO (Fig. 21) is located $150 \mathrm{n}$. miles from $E$ and $200 \mathrm{n}$. miles from $O$. On superimposing the independent predictions for the points $G$ and $H$ on these wave paths, extracted from Figs. 17, 18 and 20, the envelope curves (shown in Fig. 21 by actual scatter points) are found to be staggered in time.

Considering location $G$ first, it is evident that at the time the waves from the south (along $F E$ ) attained their peak, the waves from the south-west (along AO) were quite insignificant. On the otherhand, when the waves along AO reached their peak of $\mathrm{H}=28 \mathrm{ft}$ at about $0300 \mathrm{GCT}$, June 27, waves along FE had dropped off in height to about $\mathrm{H}=13 \mathrm{ft}$. Since these are significant waves - a statistical concept the significant wave height of the interfering wave trains may simply be taken as the higher of the two values, on essentially the same premise that it is valid in the uni-directional case to accept the envelope curve as the criterion of the significant wave [Wilson, 1961]. In justification of this it is possible to conceive of another approach direction to G differing by only a very small angle from that of $\mathrm{AO}$, and yielding substantially the same scatter-envelope of H-values. Obviously the interference of such two-directional waves would not summarily double the height of the significant waves by an additive process. Making the angular difference as small as we please, we reach the conclusion that the highest significant waves found for any particular direction at a particular time must define the significant wave height of the interference waves from all directions. On this basis then it is possible to hypothesize that the multi-directional (confused sea) significant wave heights at station $G$ in the northwestern area of the Gulf probably accorded with the dash-line envelope (upper diagram, Fig. 21) that could be expected to form the upper-bound to all possible sets of scatter-envelopes (such as those of FE and AO) from a multiplicity of directions. The same reasoning applies in establishing the dash-line curve for location $\mathrm{H}$ in Fig. 21, in the southwestern area of the Gulf.

It has been shown [Wilson, 1962] that it is possible to proceed from the output data of the machine wave-prediction process to the calculation of the wave energy spectrum at any point in space and time 


\section{DEEP WATER WAVES GENERATED BY HURRICANE "AUDREY" OF 1957}
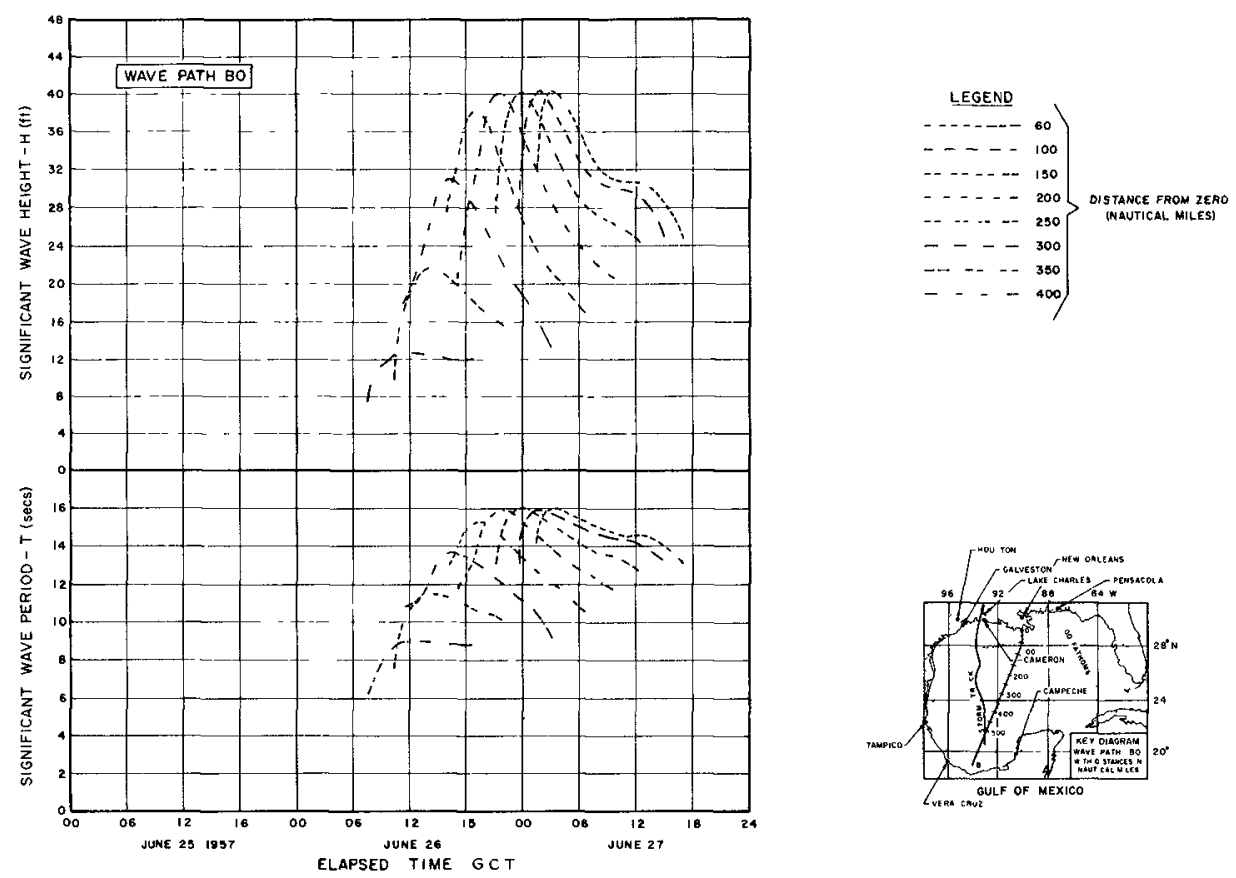

Fig. 18. Envelope histories of significant wave height and period at different distances along wave path $B O$.
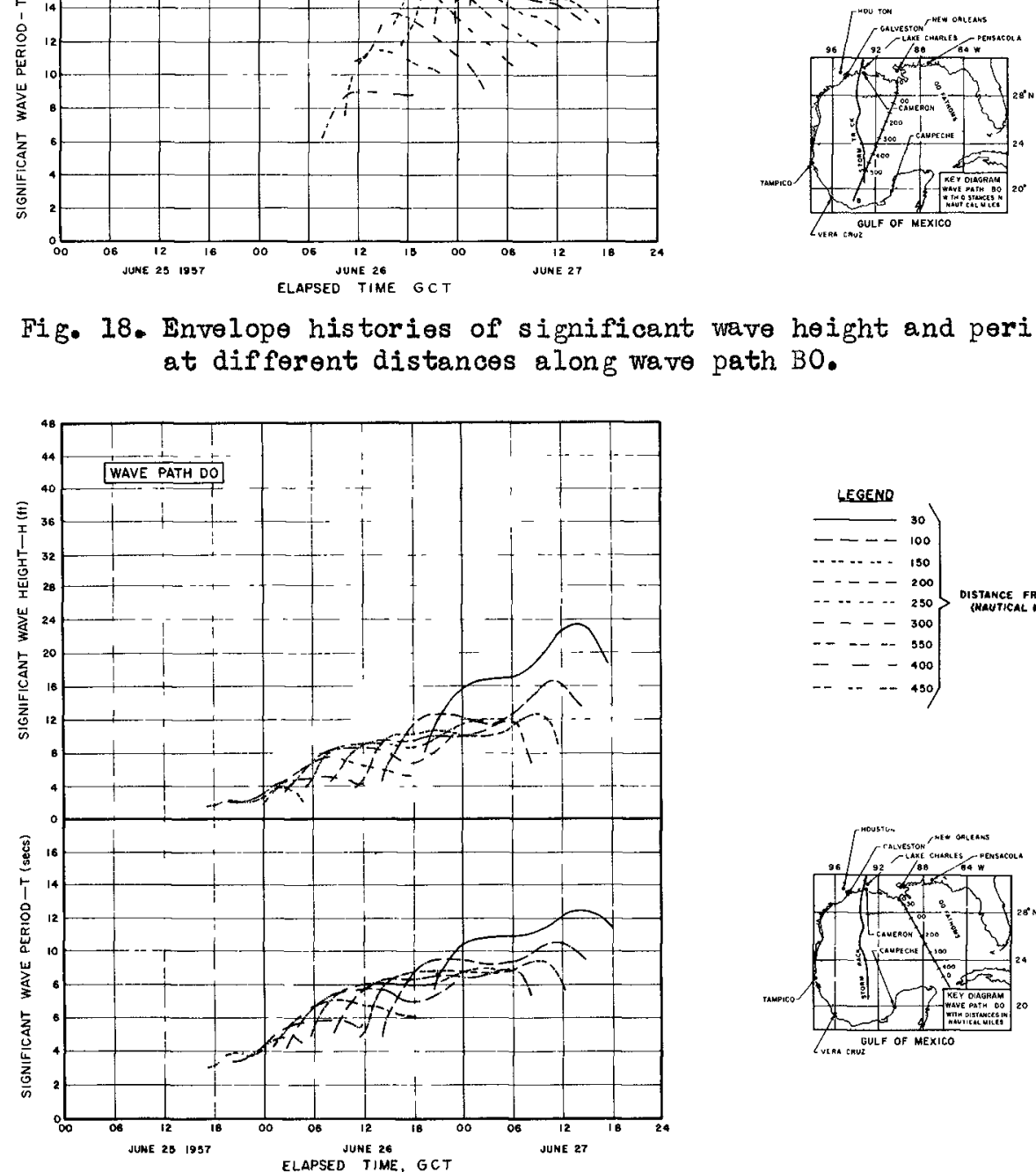

Fig. 19. Envelope histories of significant wave height and periods at different distances along wave path DO. 


\section{COASTAL ENGINEERING}

for a given wave path. This has not been done in respect of hurricane Audrey, although quite feasible. It appears possible in the light of the present paper that this development could readily be extended to arrive at the directional wave energy spectrum.

\section{CONCLUSIONS}

According to the calculations of this study hurricane Audrey was likely to have generated significant waves of a peak height of $46 \mathrm{ft}$. and period 17 secs. at the edge of the continental shelf, 100 miles from the Louisiana coast, in a direction bearing from almost due south. In terms of available hurricane wave statistics for the Gulf of Mexico [Wilson, $1957(i)(i i)]$, the storm frequency likely to produce such a result at Gilchrist, Texas (which may be considered roughly equivalent to the selected landfall station $E$ ) would be 1 in 80 years. For a hurricane of just such a frequency Reid's [1955] wave energy index would be about 68 , this being the product of the radius to maximum winds $R$ in $n$. miles and the pressure anomaly $\Delta p l=p_{n}-p_{0} ; p_{n}=$ normal pressure measured in ins of mercury. A fair value of $P_{n}$ would be $1013 \mathrm{mb}$ and for the values of $p_{o}=971 \mathrm{mb}$ and $R=55 \mathrm{n}$. miles, found in this study, we obtain the interesting result that storm wave energy index $E(=R \Delta p)=68.8$, providing very good confirmation that hurricane Audrey is probably to be classed for severity, statistically, as a storm likely to occur about once in 80 years.

Although the original objective of this study - direct confirmation of the wave prediction technique - still requires the extension of the latter into shallow water, interesting light is believed shed on the magnitudes of the deep water waves generated in the open sea during the lifetime of a hurricane. In particular some insight is obtained in the prediction of multi-directional wave effects, so evident in hurricanes.

The long and laborious task required to assess the wind structure of hurricane Audrey and its subtle changes with time would seem to preclude the possibility that the necessary input data for a numerical machine-process wave-prediction could ever be evolved in sufficient time to make accurate forecasts of waves during the lifetime of a hurricane. However, the methods here described could be developed into a successful forecasting tool by pre-calculating the waves that would be generated by a number of typical (design) hurricanes of various sizes and intensities, moving along given paths at appropriate speeds. The rapid forecasting procedure would then lie in matching the real hurricane for intensity, size, direction and speed with one of the design hurricanes and extracting the appropriate pre-calculated wave data for any desired direction of wave attack. 


\section{DEEP WATER WAVES GENERATED BY HURRICANE "AUDREY" OF 1957}
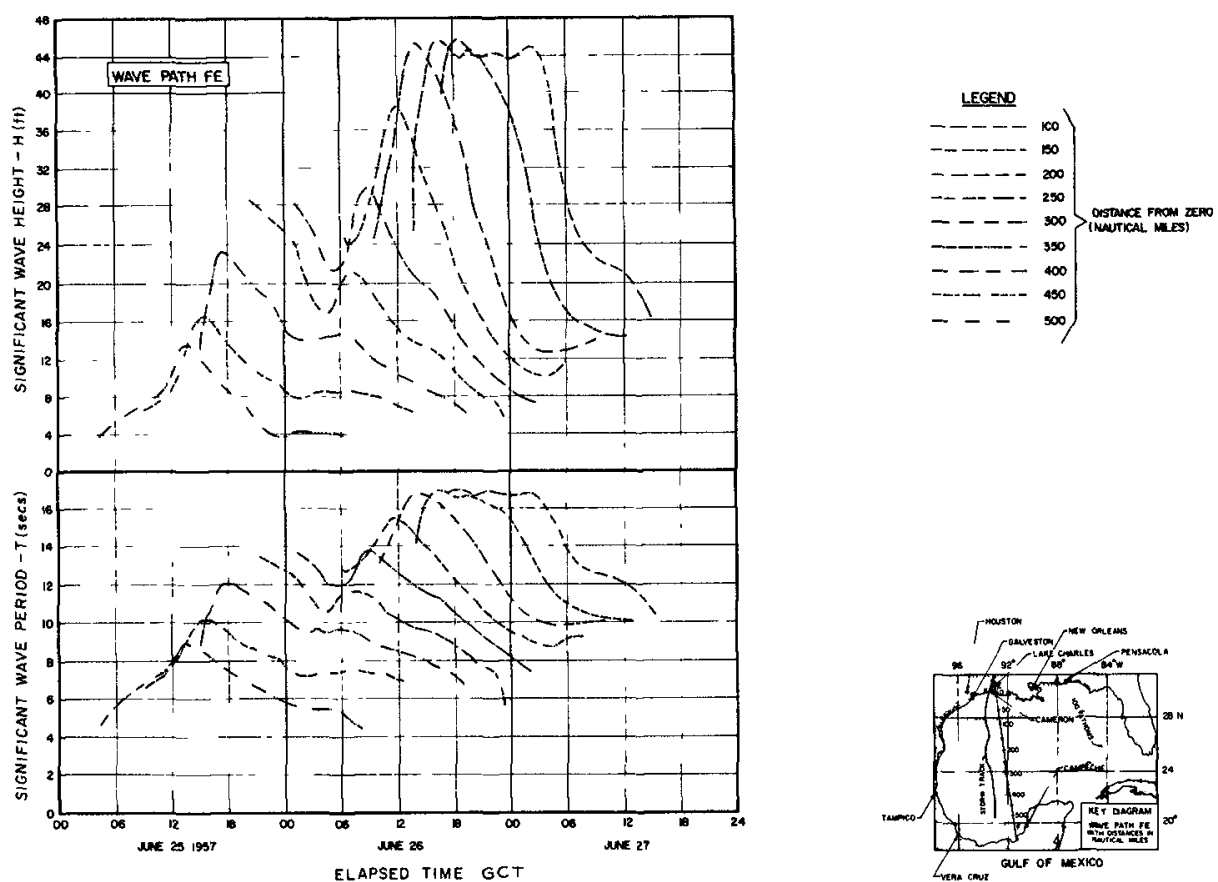

Fig. 20. Envelope historiés of significant wave height and period at different distanoes along wave path $\mathrm{FE}$.
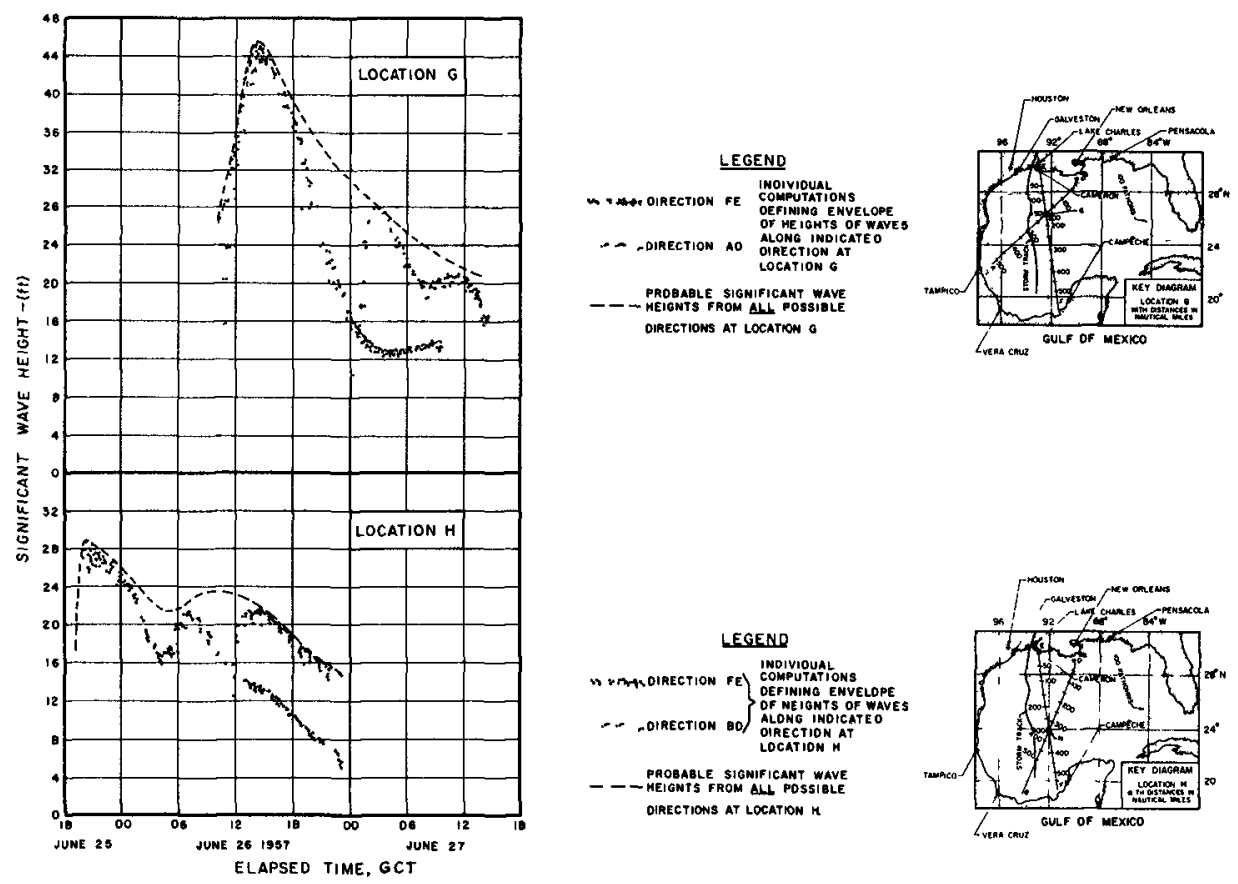

Fig. 21. Numerical computations of significant wave heights occurring at location $G$, along wave paths FW and $\mathrm{AO}$, and at location $\mathrm{H}$, along wave paths $\mathrm{FE}$ and $\mathrm{BO}$, and expected heights of significant waves from all directions at the two locations. 


\section{COASTAL ENGINEERING}

\section{ACKNOWLEDGEMENT}

The writer wishes to acknowledge with appreciation the joint support of the Engineering Foundation of New York, the Magnolia Oil Company of Texas, the Humble Oil and Refining Company of Houston and the Office of Naval Research (Contract No. N7 ONR 48702), which made possible the major part of the work reported in this paper. To the National Engineering Scrence Company, however, belongs the credit for independently supporting the final preparation and presentation of this work. The ready co-operation of Mr. A. H. Glenn in furnishing valuable data to the project is worthy of special mention, although to all who likewise contributed information the writer would record his sincere thanks. The writer is particularly grateful to Mr. R. E. Kilmer who programmed and conducted the numerical calculations on the No. 704 and 709 IBM electronic computers at the Data Processing Center, A \& M College of Texas.

\section{REFERENCES}

Corps of Engineers, U. S. Army [1957]; Hurricane Audrey, 1957; Report to 4th Meeting Hurricane Survey Co-ordinating Committee, New York, N. Y., Oct 22-23, 1957, 4 pp.

Cross, R. V. [1957]; Hurricane Audrey, June 26-28, 1957; Report to the California Co., 1957 (unpublished).

Freeport Sulphur Co. [1959]; Miscellaneous data for Port Sulphur, Grand Ecaille, Bay St. Elaine, Cocodrie and Garden Island Bay; Freeport Sulphur Co., New Orleans, La., 1957 (unpublished).

Glenn, A. H. [1959]; Supplied weather maps, wind records, report (see Lindblom), and sundry other data, A. H. Glenn \& Associates, New Orleans, La.

Graham, H. E. and Hudson, G. N. [1960]; Surface winds near the center of hurricanes (and other cyclones); Report No. 39, National Hurricane Research Project, Weather Bureau, Washington, D. C. Sept. 1960; pp. 112-123.

Harris, D. L. [1958] ; Hurricane Audrey storm tide; Report No. 23, Nat. Hurricane Research Project, Weather Bureau, Washington, D. C. , Oct. $1958 ; 19 \mathrm{pp}$. 


\section{DEEP WATER WAVES GENERATED BY HURRICANE \\ "AUDREY" OF 1957}

Hudson, G. [1957]; Pressure, wind speeds and direction in Hurricane Audrey, June 27, 1957, Report, Hydrometeorolog. Sect. , Weather Bureau, U.S. Dept. Commerce, Dec. 1957, 17 pp. (unpublished).

Kerr-McGee [ 1959], Supplied anemometer tapes for Rig 47, Block 139, Ship Shoal and Rig 48, Block 120, Vermillion, June 24-27, 1957; Kerr-McGee O1l Industries, Inc., Morgan City, La.

Lindblom, D. E. [1957]; Meteorological-oceanographic conditions over the Loulsiana-North Texas coastal and offshore area during the hurricane of June 25-28, 1957, Report of A. H. Glenn \& Assoc1ates, Nov. 1957 (unpublished).

Moore, P. L. et al [1957]; The hurricane season of 1957; Monthly Weather Rev,, Dec. 1957, pp. 401-408.

Myers, V. A. [1954]; Characteristics of United States hurricanes pertinent to levee design for Lake Okeechobee, Florida, Hydrometeorolog. Report No. 32, Weather Bureau, U. S. Dept. of Commerce, Washington, D. C., Mar. 1954, 106 pp.

Reid, R. O. [1955]; On the classification of hurricanes by storm tide and wave energy indices, Meteorological Monographs (Am. Met. Soc.), v. 2(10); June 1957, pp. 58-66.

Ross, R. B. and Blum, M. D. [1957]; Hurricane Audrey, 1957; Monthly Weather Rev., June 1957, pp. 221-223.

Sartain, R. R. [1957], Offshore damage - hurricane "Audrey", Preliminary Report, Gulf Oil Corporation, July 16, 1957, 11 pp. (unpublished).

Servicıo Meteorologico Mexico [1959], Observaciones simultaneas, Junio 23-28, 1957; Centro de Prevision del Golfo de Mexico, Instituto de Meteorologia Nautıca, Veracruz, Ver., Mexico; 1957 (unpublished).

Skjelbreia, L. [1958]; Storm data obtained in the Gulf of Mexico during the hurricane season, 1957; Proc. 1st Tech. Conf. on Hurricanes, (Miami, Fla., Nov. 1958), Am. Met. Soc., 1959. 


\section{COASTAL ENGINEERING}

Visser, R. C. [1957]; Hurricane Audrey; Report to the Shell Oil Company, 1957 (unpublished)

Weather Bureau [1958]; Index of assembled meteorological data related to hurricane "AUDREY", $2330 \mathrm{EST}$, June 24 through $0500 \mathrm{EST}$, June 28, 1957; National Weather Records Center, Ashville, North Carolina; 1958.

Wilson, B. W. [1955]; Graphical approach to the forecasting of waves in moving fetches; Tech Memo No. 73, Beach Erosion Board, Corps of Engineers, U. S. Army, April 1955, 31 pp.

Wilson, B. W. [1957(i)]; Hurricane wave statistics for the Gulf of Mexico; Tech Memo No. 98, Beach Erosion Board, Corps of Engineers, U.S. Army, June, 1957, 95 pp.

Wilson, B. W. [1957(ii)]; Hurricane wave statistics for the Gulf of Mexico; Proc. 6th Coast. Eng. Conf. (Gainsville, Fla., Dec. 1957), Council Wave Research, Berkeley, 1958.

Wilson, B. W. [1957(iii)]; Incipient wind-generation of ocean waves by a norther; Bulln. Am. Met. Soc, v. 38(7), Sept. 1957, pp. 399404.

Wilson, B. W. [1961]; Deep water wave generation by moving wind systems; Proc. ASCE, v. 87(WW2), May 1961, pp. 113-141.

Wilson, B. W. [1962]; Deep water wave generation by moving wind systems; Proc, ASCE, v. 88(WW3), Aug. 1962, pp. 175-185.

Zumwalt, T. H. [1958]; Louisiana and Texas Hurricanes; Paper presented to joint meeting Louisiana and Texas sections ASCE, Beaumont, Texas, May 1958, 24 pp. (unpublished). 